\title{
Hexane extract from Spondias tuberosa (Anacardiaceae) leaves has antioxidant activity and is an anti-Candida agent by causing mitochondrial and lysosomal damages
}

Bruna Maria Pereira da Costa Cordeiro' ${ }^{1}$ Nataly Diniz de Lima Santos ${ }^{1}$, Magda Rhayanny Assunção Ferreira², Larissa Cardoso Corrêa de Araújo ${ }^{1}$, Alexsander Rodrigues Carvalho Juniorr ${ }^{3}$, Alan Diego da Conceição Santos ${ }^{4}$, Ana Paula de Oliveira ${ }^{4}$, Alexandre Gomes da Silva ${ }^{5,6}$, Emerson Peter da Silva Falcão ${ }^{7}$, Maria Tereza dos Santos Correia', Jackson Roberto Guedes da Silva Almeida ${ }^{4}$, Luís Cláudio Nascimento da Silva ${ }^{3}$, Luiz Alberto Lira Soares², Thiago Henrique Napoleão ${ }^{1}$, Márcia Vanusa da Silva ${ }^{1,6}$ and Patrícia Maria Guedes Paiva ${ }^{1 *}$

\begin{abstract}
Background: Spondias tuberosa is a plant that produces a fruit crop with high economic relevance at Brazilian Caatinga. Its roots and leaves are used in folk medicine.

Methods: Chemical composition of a hexane extract from S. tuberosa leaves was evaluated by thin-layer chromatography (TLC), high-performance liquid chromatography (HPLC) and ${ }^{1} \mathrm{H}$ nuclear magnetic resonance (NMR). Antioxidant potential was investigated by DPPH and ABTS assays. Antifungal action on Candida species was evaluated determining the minimal inhibitory concentration $\left(\mathrm{MIC}_{50}\right)$ and putative mechanisms were determined by flow cytometry analysis. In addition, hemolytic activity on human erythrocytes was assessed and the concentration required to promote $50 \%$ hemolysis $\left(E_{50}\right)$ was determined.
\end{abstract}

Results: Phytochemical analysis by TLC showed the presence of flavonoids, hydrolysable tannins, saponins and terpenes. The HPLC profile of the extract suggested the presence of gallic acid $(0.28 \pm 0.01 \mathrm{~g} \%)$ and hyperoside (1. $27 \pm 0.01 \mathrm{~g} \%)$. The representative ${ }^{1} \mathrm{H}$ NMR spectrum showed saturated and unsaturated fatty acids among the main components. The extract showed weak and moderate antioxidant activity in DPPH (IC $50: 234.00 \mu \mathrm{g} / \mathrm{mL})$ and ABTS $\left(\mathrm{IC}_{50}: 123.33 \mu \mathrm{g} / \mathrm{mL}\right)$ assays, respectively. It was able to inhibit the growth of $C$. albicans and C. glabrata with $\mathrm{MIC}_{50}$ of 2.0 and $0.078 \mathrm{mg} / \mathrm{mL}$, respectively. The treatment of C. glabrata cells with the extract increased levels of mitochondrial superoxide anion, caused hyperpolarization of mitochondrial membrane, and compromised the lysosomal membrane. Weak hemolytic activity $\left(\mathrm{EC}_{50}: 740.8 \mathrm{\mu g} / \mathrm{mL}\right)$ was detected.

Conclusion: The results demonstrate the pharmacological potential of the extract as antioxidant and antifungal agent, aggregating biotechnological value to this plant and stimulating its conservation.

Keywords: Spondias tuberosa, Hyperoside, Gallic acid, Fatty acids, Antifungal activity

\footnotetext{
* Correspondence: ppaivaufpe@yahoo.com.br

'Departamento de Bioquímica, Centro de Biociências, Universidade Federal

de Pernambuco, Recife, Pernambuco 50670-420, Brazil

Full list of author information is available at the end of the article
}

(c) The Author(s). 2018 Open Access This article is distributed under the terms of the Creative Commons Attribution 4.0 International License (http://creativecommons.org/licenses/by/4.0/), which permits unrestricted use, distribution, and reproduction in any medium, provided you give appropriate credit to the original author(s) and the source, provide a link to the Creative Commons license, and indicate if changes were made. The Creative Commons Public Domain Dedication waiver (http://creativecommons.org/publicdomain/zero/1.0/) applies to the data made available in this article, unless otherwise stated. 


\section{Background}

Brazil has one of the world highest levels of plant diversity and the north and northeast regions of the country concentrate much of this diversity. In the semi-arid region of northeastern Brazil (known as Caatinga) there are several kinds of plants employed in popular culture for the treatment of human diseases. In spite of the great diversity of Caatinga, there are still few studies on the potential of bioactive compounds coming from the plants of this region [1-3].

Spondias tuberosa Arruda, popularly known as "umbuzeiro" or "imbuzeiro", is an endemic plant of Caatinga, adapted to survive and produce fruits even under hydrical and salt stress [4]. Several medicinal properties of $S$. tuberosa have been described, including treatment of digestive disorders, diabetes, menstrual cramps, diarrhea, inflammation of the kidneys, bacterial infections, and foot pain [5-7]. Tannins and flavonoids are found in the bark [8] and the fruits contain anthocyanins, ascorbic acid, minerals, flavonoids and carotenoids [9]. The high tannin content and the presence of natural antioxidants give to $S$. tuberosa fruits a functional appeal [10]. Hydroethanolic extract of leaves from $S$. tuberosa containing chlorogenic acid, caffeic acid, rutin and isoquercitrin demonstrated anti-inflammatory action [11]. Methanolic extract of the leaves showed in vitro activity against several strains of Gram-negative bacteria [2].

The chemical characterization of plant extracts allows the identification of chemical markers and suggests potential bioactivities that can be investigated. For example, flavonoids are secondary metabolites that have great pharmacological importance, since they act in the prevention of degenerative diseases. Among the biological properties described for these compounds, it can be highlighted cytotoxic, thrombolytic, anti-inflammatory, antitumor, vasorelaxant and antioxidant activities [11-13]. Other phenolic compounds such as tannins and anthocyanins are also considered important antioxidant agents. Natural antioxidants play an important role in health care as they provide protection from oxidative stress and associated diseases [14].

Natural products have also been considered an important source of bioactive compounds against infectious diseases [11]. Fungal infections have increased gradually over the last 30 years, becoming one of the more relevant public health problems. Candida yeasts are among the main etiological agents of invasive fungal infections, which are responsible for high mortality and morbidity rates throughout the world [15-17]. These fungi have developed resistance mechanisms against antibiotics, favoring the persistence and progression of the infection even when antifungal therapy is adequately performed [18]. Candida albicans, Candida krusei, Candida parapsilosis and Candida glabrata are among the most prevalent causers of candidiasis $[19,20]$.
In this context, this work reports the chemical composition of a hexane extract from leaves of $S$. tuberosa as well as the evaluation of the antioxidant potential and antifungal action on Candida species. Mechanisms involved in the antifungal activity against the most sensitive species were investigated. In addition, hemolytic activity was assessed as safety parameter to determine whether the extract would be able to damage erythrocytes membrane.

\section{Methods \\ Materials}

Leaves of $S$. tuberosa were collected at the Parque Nacional do Catimbau (Coordinates 08 37'23“ S, 37 09'21" W), Buíque, Pernambuco. The plant material was identified by Dr. Alexandre Gomes da Silva, and a voucher specimen was deposited at the Instituto Agronômico de Pernambuco, Recife, Brazil, under the reference number 91,090. Plant collection was authorized (number 16806) by the Instituto Chico Mendes de Conservação da Biodiversidade (ICMBio) from Brazilian Ministry of Environment. The access was recorded (A1503A6) in the Sistema Nacional de Gestão do Patrimônio Genético e do Conhecimento Tradicional Associado (SisGen).

Stored cultures of Candida albicans (URM 5901, from ungual scales), Candida parapsilosis (URM 6951, clinical isolate), Candida glabrata (URM 4246, from blood of AIDS patient), and Candida krusei (URM 6391, from human blood) were obtained from the Culture Collection of the University Recife Mycologia (URM), Departamento de Micologia, Universidade Federal de Pernambuco (UFPE).

\section{Extract preparation}

The leaves were dried in a forced air convection oven at $45{ }^{\circ} \mathrm{C}$ until constant weight. After drying, they were powdered using Willye-type mill (model TE650; Tecnal, Brazil) and the powder was stored protected from light and moisture at $28{ }^{\circ} \mathrm{C}$ until use. The extract was prepared in a Soxhlet apparatus using $100 \mathrm{~g}$ of the powdered leaves and $1 \mathrm{~L}$ of $n$-hexane. The solvent was evaporated at $75 \mathrm{rpm}$ and $64.4{ }^{\circ} \mathrm{C}$ in a $\mathrm{HB} 10$ rotary-evaporator (IKA Works, Wilmington, NC, USA). The resulting material after solvent evaporation corresponded to the extract.

\section{Thin-layer chromatography}

An amount of $1 \mathrm{mg}$ of the extract was dissolved in $1 \mathrm{~mL}$ of methanol. The sample was taken to the ultrasound for 30 min for complete solubilization. All standards (Table 1) were used at the concentration of $1 \mathrm{mg} / \mathrm{mL}$ in methanol. The sample and standards were applied manually on silica gel 60-F254 chromatography plates (Macherey-Nagel, Germany) and the different mobile phases and chromogenic agents used are shown in Table 1 [21-23]. The 
Table 1 Elution systems, chromogenic agents, and standards used in the phytochemical analysis of the hexane extract from Spondias tuberosa leaves with thin-layer chromatography (TLC)

\begin{tabular}{llll}
\hline Classes & Mobile phase & Chromogenic agent & Standards \\
\hline Polyphenols (Hydrolysable tannins) & $90: 5: 5$ & NEU + PEG & Gallic acid and Ellagic acid (Sigma-Aldrich, USA) \\
Condensed tannins & $90: 5: 5$ & Chloridric vanillin & Catechin (Sigma-Aldrich, USA) \\
Flavonoids & $90: 5: 5$ & NEU + PEG & Quercetin and Rutin (Sigma-Aldrich, USA) \\
Cinnamic derivatives & $90: 5: 5$ & NEU + PEG & Caffeic acid and Chlorogenic acid (Sigma-Aldrich, USA) \\
Terpenes and steroids & $70: 30$ & Lieberman-Burchard $+\Delta$ & B-sitosterol (Sigma-Aldrich, USA) \\
Coumarins & $50: 50: 50$ & $\mathrm{KOH}+\Delta$ & Coumarin (Phytolab, Brazil) \\
Saponins & $100: 11: 11: 26$ & Lieberman-Burchard $+\Delta$ & Escin (Sigma-Aldrich, USA) \\
Reducing sugars & $50: 20: 10: 10$ & Thymol $+\mathrm{H}_{2} \mathrm{SO}_{4}$ 10\% $+\Delta$ & D-fructose (ChromaDex, USA) \\
Alkaloids & $50: 6.75: 5$ & Dragendorf & Pilocarpine nitrate (Sigma-Aldrich, USA) \\
Anthraquinones & $50: 6.75: 5$ & $\mathrm{HNO}_{3}+\mathrm{KOH} \mathrm{10 \%}$ & Sennoside A (Sigma-Aldrich, USA) \\
\hline
\end{tabular}

Systems: 90:5:5 - ethyl acetate: formic acid: water; 70:30 - toluene: acetate; 50:50:50 - ethyl eter: ethyl acetate: 10\% acetic acid (saturation); 100:11:11:26 - ethyl acetate: acetic acid: formic acid: water; 50:20:10:10 - ethyl acetate: acetic acid: formic acid: water; 50:6.75:5 - ethyl acetate; methanol; water. NEU Neu's reagent. PEG polyethylene glycol

following secondary metabolites classes were investigated: steroids, flavonoids (aglycones and heterosides), cinnamic derivatives, mono-, tri- and sesquiterpenes, alkaloids and coumarins.

\section{High-performance liquid chromatography coupled to diode array detector (HPLC-DAD) analysis}

The extract was analyzed by high-performance liquid chromatography (HPLC) in an Ultimate 3000 coupled to a diode array detector (DAD) and equipped with a binary pump (HPG-3x00RS), degasser and automatic sampler with a loop of $20 \mu \mathrm{L}$ (ACC-3000). All these equipments were from Thermo Fisher Scientific (USA). An amount of $0.25 \mathrm{~g}$ of the hexane extract was weighed, transferred to a $25-\mathrm{mL}$ volumetric flask and diluted with methanol. The solution was taken to the sonicator during $15 \mathrm{~min}$ to complete solubilization (stock solution). After solubilization, an aliquot $(1 \mathrm{~mL})$ of the stock solution was transferred to a $10-\mathrm{mL}$ volumetric flask and the volume was completed with ultrapure water (Purelab ${ }^{\circ}$, Elga LabWater, USA). Hyperoside (HWI Analytic Gmb, Germany) and gallic acid (Sigma-Aldrich, USA) solutions $(1 \mathrm{mg} / \mathrm{mL}$ in methanol) were used as standards. The sample solution and standard solutions were filtered ( $0.45 \mu \mathrm{m}$ PVDF membrane). The chromatography was performed in a Dionex ${ }^{\circ} \mathrm{C}_{18}$ column ( $250 \mathrm{~mm} \times 4.6 \mathrm{~mm}$ d.i., $5 \mu \mathrm{m}$ ) equipped with a Phenomenex ${ }^{\circ} \mathrm{C}_{18}$ pre-column $(4 \mathrm{~mm} \times 3.9 \mu \mathrm{m})$ at $26^{\circ} \mathrm{C}$. The wavelengths were set at 270 and $350 \mathrm{~nm}$ for detection of hydrolysable tannins and flavonoids, respectively. The mobile phase was composed by ultrapure water (A) and methanol (B), both acidified with $0.05 \%(v / v)$ trifluoroacetic acid, and the flow rate was adjusted to $0.8 \mathrm{~mL} / \mathrm{min}$. The following gradient program was used: $0-10 \mathrm{~min}, 5-20 \% \mathrm{~B}$; 10-13.5 min, $20-25 \%$ B; $13.5-18 \mathrm{~min}, 25-40 \%$ B; $18-$ 25 min, $40-80 \%$ B; $25-30$ min, $80 \%$ B; 30-34 min, 80-5\% B; 34-36 min, 5\% B. The data were analyzed and processed using the software Chromeleon 6.8 (Dionex, Thermo Fisher Scientific, USA). The peaks of substances in the hexane extract were identified by comparing the retention times, UV spectra and subsequently, by spiking the sample with a small amount of the standards. The contents of hyperoside and gallic acid in the extract were calculated based on calibration curve obtained by chromatography of each standard at different concentrations: hyperoside $-y=$ $3.8841 x-11.663\left(R^{2}=0.9987\right)$; gallic acid $-y=1.2097 x-$ $0.9732\left(R^{2}=0.9996\right)$. The results were expressed as mean \pm standard deviation.

\section{Nuclear magnetic resonance (NMR) experiments}

One-dimensional and two-dimensional nuclear magnetic resonance (NMR) experiments were acquired in deuterated dimethylsulfoxide (DMSO- $\mathrm{d}_{6}$ ), using NMR Bruker AVANCE III 400 spectrometer, operating at 9.4 Tesla, observing ${ }^{1} \mathrm{H}$ and ${ }^{13} \mathrm{C}$ nuclei at 400 and $100 \mathrm{MHz}$, respectively. The spectrometer was equipped with 5-mm multinuclear direct detection probe (BBO). Due to the low sample concentration and the presence of water in the deuterated solvent, ${ }^{1} \mathrm{H}$ NMR spectra were acquired through $z g$ (classical pulse sequence) and zgpr (for water signal suppression). Besides, one-bond heteronuclear $\left({ }^{1} \mathrm{H}_{-}{ }^{13} \mathrm{C}\right)$ and homonuclear $\left({ }^{1} \mathrm{H}_{-}{ }^{1} \mathrm{H}\right)$ correlations were assessed by HSQC and COSY experiments. ${ }^{1} \mathrm{H}$ and ${ }^{13} \mathrm{C}$ NMR chemical shifts are given in ppm referenced to TMSP- $d_{4}$ signal at $0.00 \mathrm{ppm}$.

\section{Antioxidant activity}

Free radical scavenging activity by DPPH (2,2-diphenyl-1picrylhydrazyl) assay

Antioxidant activity of the hexane extract was evaluated by the DPPH scavenging assay according to Mascato et al. [24], with some modifications. The hexane extract was diluted in methanol to reach concentrations ranging from 15.625 to $1000 \mu \mathrm{g} / \mathrm{mL}$. In each assay, $270 \mu \mathrm{L}$ of the DPPH 
solution $(23.6 \mu \mathrm{g} / \mathrm{mL}$ in methanol, prepared on the day of the analysis) was added to the sample $(30 \mu \mathrm{L})$. Methanol $(30 \mu \mathrm{L})$ was used in the negative control. After $30 \mathrm{~min}$ in the dark, the reduction of DPPH was determined by measuring the colorimetric change at $517 \mathrm{~nm}$. Ascorbic acid $(0.5,1,2,3$ and $4 \mu \mathrm{g} / \mathrm{mL}$, in ethanol) was used as standard. The antioxidant concentration required to decrease $50 \%$ of the $\mathrm{DPPH}$ present $\left(\mathrm{IC}_{50}\right)$ was determined by exponential regression analysis. Two independent experiments were performed in triplicate. Samples were classified according to the $\mathrm{IC}_{50}$ as follows: $\mathrm{IC}_{50}<50 \mu \mathrm{g} / \mathrm{mL}$, very strong antioxidant; $50<\mathrm{IC}_{50}<100 \mu \mathrm{g} / \mathrm{mL}$, strong antioxidant, $101<\mathrm{IC}_{50}<150 \mu \mathrm{g} / \mathrm{mL}$, moderate antioxidant; $\mathrm{IC}_{50}>150 \mu \mathrm{g} / \mathrm{mL}$, weak antioxidant [25].

\section{ABTS [2,2'-azino-bis(3-ethylbenzothiazoline-6-sulfonic acid] assay}

The radical $\mathrm{ABTS}^{+}$was generated by oxidation of an $\mathrm{ABTS}$ solution $(7 \mathrm{mM})$ with $2.45 \mathrm{mM}$ potassium persulfate solution. The mixture was allowed to react for $12 \mathrm{~h}$ in the dark at $25{ }^{\circ} \mathrm{C}$ before use. For the test, the $\mathrm{ABTS}^{+}$stock solution $(1 \mathrm{~mL})$ was diluted in $60 \mathrm{~mL}$ of methanol to obtain an absorbance of $0.70 \pm 0.02$ at $734 \mathrm{~nm}$. Next, $2.7 \mathrm{~mL}$ of this solution was added to $0.3 \mathrm{~mL}$ of $0.5,1.0,2.0,3.0,4.0$ and $5.0 \mu \mathrm{g} / \mathrm{mL}^{\text {Trolox }}{ }^{\circ}$ (standard) solutions prepared in methanol or 31.25, 62.5, 125, 250, 500 and $1000 \mu \mathrm{g} / \mathrm{mL}$ of extract. The absorbance was taken 6 min after the adding of the radical at $734 \mathrm{~nm}$. The test was performed in triplicate. The extract concentration required to decrease $50 \%$ of the $\mathrm{ABTS}^{+}$content $\left(\mathrm{IC}_{50}\right)$ was determined by linear regression. Samples were classified according to the $\mathrm{IC}_{50}$ as described in the previous section.

\section{Antifungal assay}

The yeasts were cultured in Sabouraud Dextrose Broth (SDB) at $28{ }^{\circ} \mathrm{C}$ for $16 \mathrm{~h}$ under gentle shaking. Next, the optical density at $600 \mathrm{~nm}\left(\mathrm{OD}_{600}\right)$ of the cultures was adjusted in order to correspond to $3 \times 10^{6} \mathrm{CFU} / \mathrm{mL}$. In each row of a 96-well microplate, $100 \mu \mathrm{L}$ of the hexane extract $(8.0 \mathrm{mg} / \mathrm{mL})$ were serially diluted (1:1) in SDB and $20 \mu \mathrm{L}$ of yeast culture were added to each well. Wells containing only the culture medium were used as sterility control while the $100 \%$ growth control contained the microorganism in culture medium. In addition, it was performed a blank composed by the extract diluted in culture medium. The $\mathrm{OD}_{600}$ was recorded at time zero and after incubation at $28{ }^{\circ} \mathrm{C}$ for $24 \mathrm{~h}$. The increase in $\mathrm{OD}_{600}$ was considered as fungal growth. The minimal inhibitory concentration $\left(\mathrm{MIC}_{50}\right)$ corresponded to the lowest extract concentration able to promote a reduction higher or equal to $50 \%$ in growth. Each assay was achieved in triplicate and three independent experiments were performed.

The supernatant $(10 \mu \mathrm{L})$ from each well containing the extract at concentration higher or equal to the $\mathrm{MIC}_{50}$ was transferred to Sabouraud-Dextrose Agar plates and incubated for $24 \mathrm{~h}$. The minimal fungicidal concentration (MFC) corresponded to the lowest extract concentration able to reduce the number of CFU in $99.9 \%$. Each assay was carried out in triplicate in three independent experiments.

\section{Flow cytometry analysis}

Fluorescent probes were used in order to analyze putative effects of the extract on mitochondrial superoxide production, the mitochondrial membrane potential, and lysosomal membrane of C. glabrata cells. In all these assays, yeast cells were resuspended at a density of $1 \times 10^{6}$ cells/mL in RPMI-1640 medium supplemented with MOPS. The extract was added at the concentrations of $2 \times \operatorname{MIC}(0.156 \mathrm{mg} / \mathrm{mL})$ or $4 \times \operatorname{MIC}(0.312 \mathrm{mg} / \mathrm{mL})$, and the cells were incubated at $28{ }^{\circ} \mathrm{C}$.

For measurement of mitochondrial superoxide production, the extract was added and, after $1 \mathrm{~h}$, the medium was removed, and the cells were washed using PBS. Then the MitoSOX Red mitochondrial superoxide indicator (Molecular Probes, Invitrogen, Carslabad, CA, USA) at $5 \mu \mathrm{M}$ was added and the samples were incubated for $10 \mathrm{~min}$ at $37^{\circ} \mathrm{C}$, protected from light. The cells were washed with warm buffer (three times) and analyzed by flow cytometry (FL3 channel, Accuri ${ }^{\mathrm{m}}$, BD Biosciences, San Jose, CA, USA).

In other assays, cells were incubated with extract for $12 \mathrm{~h}$ and then washed with PBS and stained with $1 \mu \mathrm{g} /$ $\mathrm{mL}$ acridine orange (lysosomal dye) in the dark for $20 \mathrm{~min}$ or $10 \mu \mathrm{g} / \mathrm{mL}$ rhodamine 123 (to assay mitochondrial membrane potential change) in the dark for $10 \mathrm{~min}$. After the incubation, yeast cells were washed and analyzed by flow cytometry (FL3 channel and FL1 channel for acridine orange and rhodamine 123. respectively). A minimum of 10,000 events were analyzed in each condition. Changes in the fluorescent intensity of rhodamine 123 were quantified using the variation index (VI) obtained by the eq. (MT-MC)/MC, where $\mathrm{MC}$ is the mean of fluorescent intensity of control and MT the mean of treated cells. Negative values of VI correspond to membrane depolarization of mitochondria, while positive values indicate membrane hyperpolarization.

\section{Hemolytic assay}

The hexane extract was evaluated for hemolytic activity in 96-well microplates according to Costa-Lotufo et al. [26]. Each well received $100 \mu \mathrm{L}$ of a $0.85 \%(w / v) \mathrm{NaCl}$ solution containing $10 \mathrm{mM} \mathrm{CaCl}_{2}$. Next, samples $(100 \mu \mathrm{L})$ of the extract at 10 to $2500 \mu \mathrm{g} / \mathrm{mL}$ were added to the wells. Finally, each well received $100 \mu \mathrm{L}$ of a $2 \%(v / v)$ suspension of human erythrocytes in $0.85 \%$ saline containing $10 \mathrm{mM}$ $\mathrm{CaCl}_{2}$. In negative control, $150 \mu \mathrm{L}$ of the saline solution plus $50 \mu \mathrm{L}$ of $5 \%(\mathrm{v} / \mathrm{v})$ DMSO were plated. Positive 
control (to obtain $100 \%$ hemolysis) contained $20 \mu \mathrm{L}$ of $0.1 \%(\mathrm{v} / \mathrm{v})$ Triton X-100 in $180 \mu \mathrm{L}$ of saline solution. After incubation for $1 \mathrm{~h}$ at $27^{\circ} \mathrm{C}$ and centrifugation, the supernatant was discarded, and the amount of released hemoglobin was measured by absorbance at $540 \mathrm{~nm}$. Three independent experiments were performed in triplicate. Extract was considered active whether the $\mathrm{EC}_{50}$ value was lower than $200 \mu \mathrm{g} / \mathrm{mL}$ [26].

\section{Statistical analysis}

Standard deviations (SD) were calculated using GraphPad Prism version 4.0 for Windows (GraphPad Software, San Diego, California, USA) and data were expressed as a mean of replicates \pm SD. Significant differences between treatment groups were analysed by Student's $t$-test (significance at $p<0.05$ ) using Origin 6.0 program.

\section{Results}

The phytochemical analysis by TLC of the hexane extract from $S$. tuberosa leaves showed the presence of flavonoids, hydrolysable tannins, saponins and terpenes. The HPLC profile of the extract at $270 \mathrm{~nm}$ (Fig. 1A, a) showed three main peaks (retention times 10.197, 25.403 and $26.223 \mathrm{~min}$ ). The first peak probably corresponded to gallic acid (peak 1), in comparison with retention time of the standard (10.23 min; Fig. 1A, b). The chromatogram at $350 \mathrm{~nm}$ (Fig. 1B, a) showed main a peak at $25.433 \mathrm{~min}$, which corresponds to a flavonoid (peak 2) since it was also observed at $270 \mathrm{~nm}$. According to the retention time of the standard hyperoside (Fig. 1B, b), this peak is similar to this compound. These results were confirmed by the increase in the area after spiking the extract with the standards gallic acid (Fig. 1A, c) and hyperoside (Fig. 1B, c). The equivalent contents of
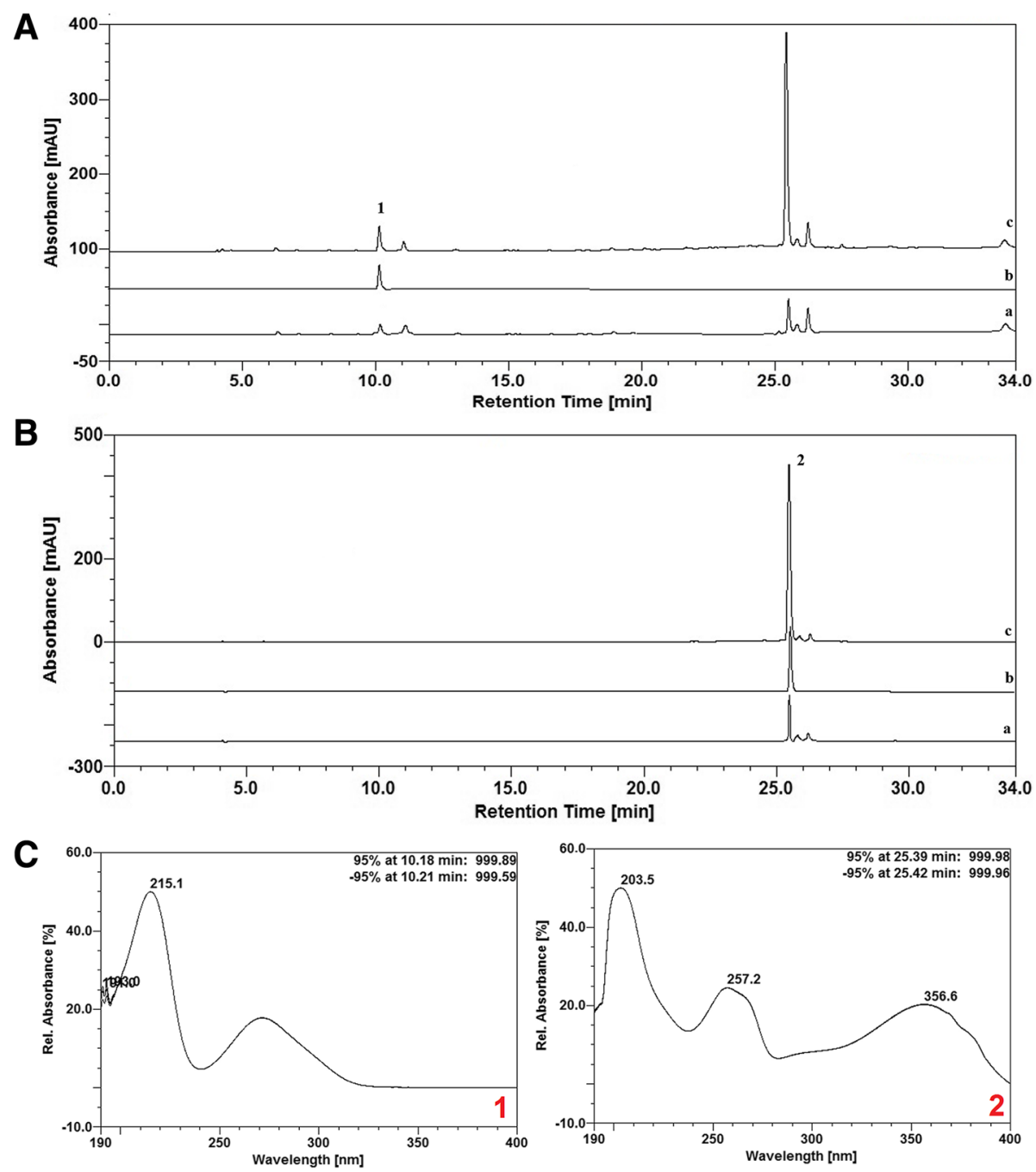

Fig. 1 HPLC-DAD analysis of hexane extract from Spondias tuberosa leaf. Chromatographic fingerprint at 270 (a) and 350 (b) nm showed the presence of gallic acid (1) and hyperoside (2), as indicated by the retention times. c Scanning spectra of peaks 1 and 2 
hyperoside and gallic acid calculated were $1.27 \pm$ $0.01 \mathrm{~g} \%$ and $0.28 \pm 0.01 \mathrm{~g} \%$, respectively.

The representative ${ }^{1} \mathrm{H}$ NMR spectrum of hexane extract of $S$. tuberosa leaves revealed typical signals of fatty acid methyl esters (Fig. 2), which is expected for an extract obtained using a non-polar solvent. The resonances related to aliphatic hydrogens of all fatty acids can also be visualized in the figure. Methylene groups appeared at 1.16$1.35 \mathrm{ppm}$, while the signal at $1.49 \mathrm{ppm}$ corresponds to $\beta$ carbonyl group hydrogens. Characteristic resonances of methylene alpha-olefins of all unsaturated fatty acids were observed at $1.98 \mathrm{ppm}$. The presence of methylene hydrogens between two olefins and alpha carbonyl hydrogens could be noticed at 2.77 and $2.34 \mathrm{ppm}$, respectively. The signal at $0.84 \mathrm{ppm}$ corresponds to methyl groups of all fatty acids, except for the methylic hydrogens of $n-3$ polyunsaturated acyl groups that are easily identified as a triplet at $1.06 \mathrm{ppm}[27,28]$. It should be pointed out that the fatty acid acyl chains are not esterified to glycerol backbone, as typical signals of it were not observed. Another way of corroborating such information would be by checking the signal around $3.67 \mathrm{ppm}$, which is associated with the methoxy group of fatty acid methyl esters. However, in our experiment the residual water signal compromised the obtainment of such information. Finally, the signal at $5.33 \mathrm{ppm}$ (olefinic hydrogens) connected to the carbon at $129.5 \mathrm{ppm}$ indicated the presence of unsaturated fatty acids. The presence of hydrogens of phenolic compounds could be observed by signals between 6 and 8 ppm.

The hexane extract was evaluated for antioxidant activity by the DPPH scavenging assay. The results showed that the increase in the extract concentration led to higher inhibition of this free radical. An $\mathrm{IC}_{50}$ value of $234 \mu \mathrm{g} / \mathrm{mL}$ was calculated. The results from ABTS assay showed that the $\mathrm{IC}_{50}$ values were 123.33 and $1.72 \mu \mathrm{g} / \mathrm{mL}$ for the hexane extract and the positive control Trolox ${ }^{\circ}$, respectively.

The antifungal assays showed that the hexane extract was able to inhibit the growth of $C$. albicans and $C$. glabrata with $\mathrm{MIC}_{50}$ values of 2.0 and $0.078 \mathrm{mg} / \mathrm{mL}$, respectively. Candida parapsilosis and C. krusei did not have their growth affected by the extract. Fungicidal effect was not detected.

The effect of the extract on superoxide production by C. glabrata cells was evaluated. The results (Fig. 3A) showed that low levels of fluorescence were detected in untreated cells while high levels of mitochondrial superoxide anion were induced by treatment with the extract for $1 \mathrm{~h}$ (5.8 and 5.2 folds for $2 \times \mathrm{MIC}_{50}$ and $4 \times \mathrm{MIC}_{50}$, respectively, when compared with untreated yeasts). No statistical differences were observed between the amount of superoxide induced by the two concentrations tested.

Alterations in mitochondrial functions induced by the extract were evaluated by measuring changes the mitochondrial membrane potential $(\Delta \Psi \mathrm{m})$ using the variation index (VI). Healthy cells incorporated the probe rhodamine 123 and showed high levels of fluorescence emission. The fluorescence intensity was significantly increased by extract treatment when compared with untreated cells (Fig. 3B), resulting in positive VI values (7.65 folds for $2 \times \mathrm{MIC}_{50}$ and 5.15 folds for $4 \times \mathrm{MIC}_{50}$ ).

The lysosomal function was analyzed using an acridine orange-based assay. As expected, the yeast cells that were not treated with the extract exhibited a strong fluorescence

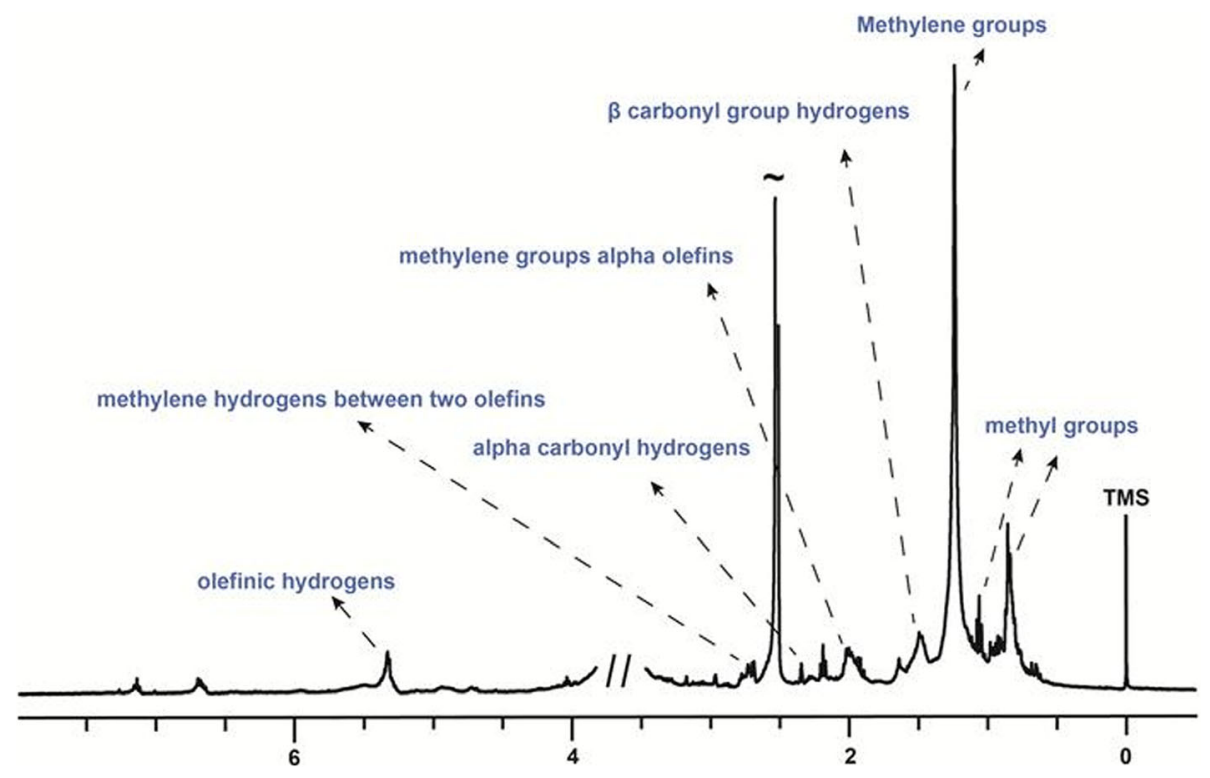

Fig. 2 Representative ${ }^{1} \mathrm{H}$ NMR spectrum of hexane extract of Spondias tuberosa leaf 
A
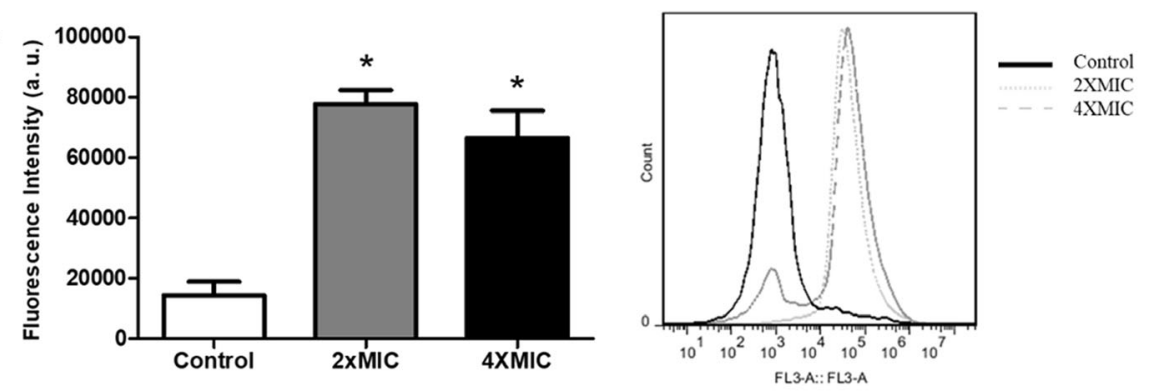

B


Fig. 3 Investigation of antifungal mechanisms of hexane extract from Spondias tuberosa leaf against Candida glabrata. It was evaluated the effects of extract treatment on the production of mitochondrial superoxide anion (a), mitochondrial membrane potential (b) lysosomal membrane stability $(\mathbf{c}) .\left(^{*}\right)$ Significant differences compared with untreated cells (control). Minimal inhibitory concentration $\left(\mathrm{MIC}_{50}\right) \mathrm{Was} 0.078 \mathrm{mg} / \mathrm{mL}$

emission, confirming that these cells had intact lysosomes. On the other hand, the extract treatment compromised the lysosomal membrane of C. glabrata, as seen by the lower levels of fluorescence emission than control cells (Fig. 3C). The fluorescence emission reduced $41.98 \%$ and $26.91 \%$ when the cells were incubated with the extract at $2 \times \mathrm{MIC}_{50}$ and $4 \times \mathrm{MIC}_{50}$, respectively.

The hexane extract was also evaluated for hemolytic activity against human erythrocytes. The $\mathrm{EC}_{50}$ value determined was $740.8 \pm 61.09 \mu \mathrm{g} / \mathrm{mL}$.

\section{Discussion}

Many works have studied the chemical composition and biological activities of extracts from $S$. tuberosa tissues, including the leaves, obtained using polar organic solvents. For example, methanolic extract from S. tuberosa leaves contained phenols, tannins, flavones, flavonoids, leucoanthocyanidins and saponins [2] and Uchôa et al. [29] reported that extracts from the leaves of $S$. tuberosa in methanol and ethyl acetate were rich in flavonoids and triterpenes as well as also contained cinnamic derivatives. Analysis of a hydroethanolic extract from leaves of this plant also evidenced the presence of flavonoids [11]. In the present work, we aimed to evaluate the composition of an extract from S. tuberosa leaves obtained with hexane, a non-polar solvent. Interestingly, the classes of compounds detected by TLC were also present in the extracts mentioned above, produced using solvents with higher polarity. Particularly, the presence of flavonoids and hydrolysable tannins in the hexane extract caught our attention and stimulated a more in-depth evaluation by HPLC analysis. Indeed, the presence of compounds similar to gallic acid and hyperoside was confirmed.

Siqueira et al. [11] showed through HPLC-DAD analysis that a hydroethanolic extract of $S$. tuberosa leaves presented a large number of phenolic compounds and derivatives of flavonoids; they identified the presence of chlorogenic acid, caffeic acid, rutin, and isoquercitrin. Silva et al. [2] identified the presence of rutin, quercetin and ellagic acid in the methanolic extract of $S$. tuberosa 
leaves. These compounds were not detected in the hexane extract of $S$. tuberosa leaves described herein, which is probably due to the chemical characteristic of the hexane, which did not favor the extraction of high content of polar compounds. In spite of this, a specific flavonoid (probably hyperoside or a very similar compound) was efficiently extracted from the leaves using this solvent. The hyperoside is the 3-O-galactoside of quercetin and has been described in the literature as anticancer, anti-inflammatory, and antioxidant agent. In addition, this compound was shown to act in the protection of liver fibrosis and prevention of memory deficit [30-32].

According to the classification of Fidrianny et al. [25], the hexane extract of $S$. tuberosa leaves is considered a weak DPPH scavenger. However, the hexane extract from $S$. tuberosa leaves showed higher DPPH scavenging activity than extracts of Spondias pinnata, which showed $\mathrm{IC}_{50}$ ranging from 0.73 to $0.59 \mathrm{mg} / \mathrm{mL}$ [33]. The hyperoside possesses DPPH scavenging activity with an $\mathrm{IC}_{50}$ of $27.5 \mathrm{mM}$ [34] and polyunsaturated fatty acids may act as antioxidants [35]. Thus, flavonoids and fatty acids may be involved in the antioxidant property of the hexane extract of $S$. tuberosa leaves.

According the results from ABTS assay, the extract is a moderate antioxidant. Floegel et al. [36] reported that high-pigmented and hydrophilic antioxidants in a variety of foods were better reflected by the ABTS assay in comparison with the DPPH assay. Indeed, the hexane extract of $S$. tuberosa leaves used in this work is highly pigmented and one of its main compounds is similar to hyperoside, a water-soluble compound. This may explain the better result obtained with ABTS in comparison with DPPH assay. The antioxidant properties of hyperoside have been demonstrated; for example, it protected endothelial cells against oxidative damage by hydrogen peroxide [37].

The hexane extract showed an interesting activity against C. glabrata, as seen by its low $\mathrm{MIC}_{50}$ value. Dall'Agnol et al. [38] reported that crude extracts of Hypericum containing the hyperoside showed no activity against yeasts. On the other hand, polyunsaturated fatty acids have demonstrated antifungal properties against Candida species [39].

Given the highest activity of the hexane extract against C. glabrata (as seen by its low $\mathrm{MIC}_{50}$ value), we attempted to analyze some subcellular alterations induced by this extract. The results demonstrate that the extract induced the production of mitochondrial superoxide anion and hyperpolarization of mitochondrial membrane. In addition, the extract damaged the lysosomal membrane of $C$. glabrata cells. Lysosomal membrane damage leads to release of cathepsins from into the cytosol where they participate in apoptosis signaling [40].

According to Costa-Lotufo et al. [26], a sample must present $\mathrm{EC}_{50}<200 \mu \mathrm{g} / \mathrm{mL}$ to be considered hemolytic.
Thus, the hexane extract from $S$. tuberosa leaves is considered no hemolytic, which is initial evidence to determine its safety.

\section{Conclusion}

A hexane extract from S. tuberosa leaves containing flavonoids, hydrolysable tannins, saponins, terpenes and unsaturated fatty acids showed moderate antioxidant activity and antifungal effect on C. glabrata. Antifungal mechanisms against C. glabrata include increase in levels of mitochondrial superoxide anion, hyperpolarization of mitochondrial membrane, and damage to the lysosomal membrane. The extract showed weak hemolytic activity, which is important information for future studies to be performed at in vivo conditions. The results demonstrate the pharmacological potential of the extract, aggregating biotechnological value to this plant and stimulating its conservation.

\section{Abbreviations}

ABTS: 2,2'-azino-bis(3-ethylbenzothiazoline-6-sulfonic) acid; CFU: Colony-forming units; DMSO: Dimethylsulfoxide; DPPH: 2,2-diphenyl-1-picrylhydrazyl; $\mathrm{EC}_{50}$ : Effective concentration required to promote $50 \%$ hemolysis; HPLC

DAD: High-performance liquid chromatography coupled to diode array detector analysis; $I C_{50}$ : concentration required to decrease $50 \%$ of the free radical content: ICMBio: Instituto Chico Mendes de Conservação da Biodiversidade; MFC: Minimal fungicidal concentration; $\mathrm{MIC}_{50}$ : Minimal concentration required to inhibit growth in at least 50\%; NEU: Neu's reagent; NMR: Nuclear magnetic resonance; OD: Optical density; PBS: Phosphate-buffered saline; PEG: Polyethylene glycol; SDB: Sabouraud Dextrose Broth; SisGen: Sistema Nacional de Gestão do Patrimônio Genético e do Conhecimento Tradicional Associado; TLC: Thin-layer chromatography; UFPE: Universidade Federal de Pernambuco; URM: University Recife Mycologia (culture collection); Vl: Variation index

\section{Acknowledgments}

The authors are also grateful to Dr. Carlos Eduardo Sales da Silva for technical assistance.

\section{Funding}

The authors express their gratitude to the Conselho Nacional de

Desenvolvimento Científico e Tecnológico (CNPq) for financial support (446902/ 2014-4) and investigator research grants (MTSC, JRGSA, THN, PMGP). They are also grateful to the Coordenação de Aperfeiçoamento de Pessoal de Nível Superior (CAPES) and the Fundação de Amparo à Ciência e Tecnologia do Estado de Pernambuco (FACEPE; APQ-0108-2.08/14; APQ-0493-4.03/14; APQ0661-2.08/15) for financial support. BMPCC would like to thank CAPES for graduate scholarship. The funding body had no role in the design of the study, collection, analysis, interpretation of data, and writing the manuscript.

\section{Availability of data and materials}

The datasets used and/or analysed during the current study are available from the corresponding author on reasonable request.

\section{Authors' contributions}

BMPCC, AGS, MTSC, MVS, and PMGP conceptualized the study. BMPCC and NDLS prepared the extract. BMPCC and LCCA performed the antioxidant, antifungal and hemolytic assays. MRAS, EPSF and LALS performed the TLC and HPLC experiments and contributed to interpretation of the data. ADCS, APO and JRGSA performed the NMR experiments and interpreted the data. ARCJ and LCNS performed all the flow cytometry analysis. BMPCC, NDLS, THN and PMGP analyzed all the data. BMPCC, NDLS, MRAS, JRGSA, LCNS, THN and PMGP drafted the manuscript. All authors approved the final manuscript.

\section{Ethics approval and consent to participate}

The Ethics Committee on Humans Experimentation of the Universidade Federal de Pernambuco approved the protocols (68393217.0.0000.5208) used to collect blood for hemolytic analysis. All participants signed an informed consent. 


\section{Consent for publication}

Not applicable.

\section{Competing interests}

The authors declare that they have no competing interests.

\section{Publisher's Note}

Springer Nature remains neutral with regard to jurisdictional claims in published maps and institutional affiliations.

\section{Author details}

'Departamento de Bioquímica, Centro de Biociências, Universidade Federal de Pernambuco, Recife, Pernambuco 50670-420, Brazil. ${ }^{2}$ Departamento de Ciências Farmacêuticas, Centro de Ciências da Saúde, Universidade Federal de Pernambuco, Recife, Pernambuco 50740-520, Brazil. ${ }^{3}$ Universidade CEUMA, São Luís, Maranhão 65075-120, Brazil. ${ }^{4}$ Núcleo de Estudos e Pesquisas de Plantas Medicinais, Universidade Federal do Vale do São Francisco, Petrolina, Pernambuco 56304-205, Brazil. ${ }^{5}$ Departamento de Antibióticos, Centro de Biociências, Universidade Federal de Pernambuco, Recife, Pernambuco 50670-420, Brazil. ${ }^{6}$ Núcleo de Bioprospecção da Caatinga, Instituto Nacional do Semiárido, Campina Grande, Paraíba 58429-970, Brazil. Núcleo de Nutrição, Centro Acadêmico de Vitória, Universidade Federal de Pernambuco, Vitória de Santo Antão, Pernambuco 55608-680, Brazil.

\section{Received: 13 July 2018 Accepted: 9 October 2018}

\section{Published online: 19 October 2018}

\section{References}

1. Albuquerque UP, Monteiro JM, Almeida CFCBR, Florentino ATN, Ferraz JSF. Useful plants of the semi-arid northeastern region of Brazil - a look at their conservation and sustainable use. Environ Monitor Assess. 2007;125:281-90.

2. Silva ARA, Morais SM, Marques MMM, Oliveira DF, Barros CC, Almeida RR, Vieira IGP, Guedes MIF. Chemical composition, antioxidant and antibacterial activities of two Spondias species from northeastern Brazil. Pharm Biol. 2012;50:740-6.

3. Vieira PDB, Silva NLF, Silva GN, Silva DB, Lopes NP, Gnoatto SCB, Silva MV, Macedo AJ, Bastida J, Tasca T. Caatinga plants: natural and semi-synthetic compounds potentially active against Trichomonas vaginalis. Bioorg Med Chem Lett. 2016;26:2229-36.

4. Silva EC, Nogueira RJMCN, Araújo FP, Melo NF, Neto ADA. Physiological responses to salt stress in young umbu plants. Environ Exp Bot. 2008;63:147-57.

5. Agra MF, Baracho GS, Silva NK, Basílio IJLD, Coelho VPM. Medicinal and poisonous diversity of the flora of "Cariri Paraibano", Brazil. J Ethnopharmacol. 2007;111:383-95.

6. Neto EMFL, Peroni N, Albuquerque U. Traditional knowledge and management of Umbu (Spondias tuberosa, Anacardiaceae): an endemic species from the semi-arid region of northeastern Brazil. Econ Bot. 2010; 64:11-21.

7. Ferreira Júnior WS, Ladio AH, Albuquerque AUP. Resilience and adaptation in the use of medicinal plants with suspected anti-inflammatory activity in the Brazilian northeast. J Ethnopharmacol. 2011;138:238-52.

8. Araújo TAS, Alencar NL, Amorim ELC, Albuquerque AUP. A new approach to study medicinal plants with tannins and flavonoids contents from the local knowledge. J Ethnopharmacol. 2008;120:72-80.

9. Rufino MDSM, Alves RE, Brito ES, Pérez-Jiménez J, Saura-Calixto F, ManciniFilho J. Bioactive compounds and antioxidant capacities of 18 nontraditional tropical fruits from Brazil. Food Chem. 2010;121(4):996-1002.

10. Zeraik ML, Queiroz EF, Marcourt L, Ciclet O, Castro-Gamboa IC, Silva DHS, Cuendet M, Bolzani VS, Wolfender J-L. Antioxidants, quinone reductase inducers and acetylcholinesterase inhibitors from Spondias tuberosa fruits. J Funct Foods. 2016;21:396-405.

11. Siqueira EMS, Félix-Silva J, Araújo LML, Fernandes JM, Cabral B, Gomes JAS, Roque AA, Tomaz JC, Lopes NP, Fernandes-Pedrosa MF, Giordania RB, Zucolotto SM. Spondias tuberosa (Anacardiaceae) leaves: profiling phenolic compounds by HPLC-DAD and LC-MS/MS and in vivo anti-inflammatory activity. Biomed Chromatogr. 2016;30:1656-65.

12. Islam SMA, Ahmed KT, Manik MK, Wahid MA, Kamal CSI. A comparative study of the antioxidant, antimicrobial, cytotoxic and thrombolytic potential of the fruits and leaves of Spondias dulcis. Asian Pacif J Trop Biomed. 2013;3:682-91.
13. Cabral B, Siqueira EMS, Bitencourt MAO, Lima MCJS, Lima AK, Ortmann CF, Chaves VC, Fernandes-Pedrosa MF, Rocha HAO, Scortecci KC, Reginatto FH, Giordani RB, Zucolotto SM. Phytochemical study and anti-inflammatory and antioxidant potential of Spondias mombin leaves. Rev Bras Farmacogn. 2016; 26:304-11.

14. López V, Akerreta S, Casanova E, García-Mina JM, Cavero RY, Calvo MI. In vitro antioxidant and anti-Rhizopus activities of Lamiaceae herbal extracts. Plant Foods Hum Nutr. 2007;62:151-5.

15. Khan MSA, Ahmad I, Aqil F, Owais M, Shahid M, Musarrat J. Virulence and pathogenicity of fungal pathogens with special reference to Candida albicans. In: Ahmad I, Owais M, Shahid M, Aqil F, editors. Combating fungal infections, problems and remedy. Berlin: Springer-Verlag Berlin Heidelberg; 2010.

16. Arendrup MC. Update on antifungal resistance in Aspergillus and Candida. Clin Microbiol Infect. 2013;20:42-8.

17. Bitar I, Khalaf RA, Harastani H, Tokajian S. Identification, typing, antifungal resistance profile, and biofilm formation of Candida albicans isolates from Lebanese hospital patients. Biomed Res Int. 2014;2014:931372.

18. Kolaczkowska A, Kołaczkowski M. Drug resistance mechanisms and their regulation in non-albicans Candida species. J Antimicrob Chemother. 2016; 71:1438-50

19. Yiqing $T$, Jianguo T. Candida albicans infection and intestinal immunity. Microbiol Res. 2017;198:27-35.

20. Sharifzadeh A, Khosravi AR, Shokri H, Tari PS. Synergistic anticandidal activity of menthol in combination with itraconazole and nystatin against clinical Candida glabrata and Candida krusei isolates. Microb Pathog. 2017;107:390-6.

21. Roberts EH, Cartwright RA, Wood DJ. The flavonols of tea. J Sci Food Agric. 1956;7:637-46.

22. Wagner H, Bladt S. Plant drug analysis. New York: Springer; 1995.

23. Harborne JB. Phytochemical methods: a guide to modern techniques of plant analysis. London: Chapman \& Hall; 1998.

24. Mascato DRLH, Monteiro JB, Passarinho MM, Galeno DML, Cruz RJ, Ortiz C, Morales L, Lima ES, Carvalho RP. Evaluation of antioxidant capacity of Solanum sessiliflorum (Cubiu) extract: an in vitro assay. J Nutr Metab. 2015; 2015:364185.

25. Fidrianny l, Rizkiya A, Ruslan K. Antioxidant activities of various fruit extracts from three Solanum sp. using DPPH and ABTS method and correlation with phenolic, flavonoid and carotenoid content. J. Chem. Pharm. Res. 2015;7:666-72.

26. Costa-Lotufo LV, Khan MTH, Ather A, Wilke DV, Jimenez PC, Pessoa C, Moraes MEA, Moraes MO. Studies of the anticancer potential of plants used in Bangladeshi folk medicine. J Ethnopharmacol. 2005;99:21-30.

27. Mello VM, Oliveira FCC, Fraga WG, Nascimento CJ, Suarez PAZ. Determination of the content of fatty acid methyl esters (FAME) in biodiesel samples obtained by esterification using ${ }^{1} \mathrm{H}$-NMR spectroscopy. Magn Reson Chem. 2008:46:1051-4.

28. Nestor G, Bankefors J, Schlechtriem C, Brãnnãs E, Pickova J, Sandstróm C. High-resolution ${ }^{1} \mathrm{H}$ magic angle spinning NMR spectroscopy of intact arctic char (Salvelinus alpinus) muscle. Quantitative analysis on n-3 fatty acids, EPA and DHA. J Agric Food Chem. 2010;58:10799-803.

29. Uchôa ADA, Oliveira WF, Pereira APC, Silva AG, Cordeiro BMPC, Malafaia CB, Almeida CMA, Silva NH, Albuquerque JFC, Silva MV, Correia MTS. Antioxidant activity and phytochemical profile of Spondias tuberosa Arruda leaves extracts. Am J Plant Sci. 2015;6:3038-44.

30. Raudoné $L$, Raudonis $R$, Janulis $V$, Viškelis $P$. Quality evaluation of different preparations of dry extracts of birch (Betula pendula Roth) leaves. Nat Prod Res. 2014;28:1645-8.

31. Gong Y, Yang Y, Chen X, Yang M, Huang D, Yang R, Zhou L, Li C, Xiong Q, Xiong Z. Hyperoside protects against chronic mild stress-induced learning and memory deficits. Biomed Pharmacother. 2017;91:831-40.

32. Zou L, Chen S, Li L, Wu T. The protective effect of hyperoside on carbon tetrachloride-induced chronic liver fibrosis in mice via upregulation of Nrf2. Exp Toxicol Pathol. 2017:69:451-60

33. Satpathy G, Tyagi YK, Gupta RK. Preliminary evaluation of nutraceutical and therapeutic potential of raw Spondias pinnata $K_{\text {., }}$ an exotic fruit of India. Food Res Int. 2011:44:2076-87.

34. Sukito A, Tachibana S. Isolation of hyperoside and isoquercitrin from Camellia sasanqua as antioxidant agents. Pak J Biol Sci. 2014;17:999-1006.

35. Richard D, Kefi K, Barbe U, Bausero P, Visioli F. Polyunsaturated fatty acids as antioxidants. Pharmacol Res. 2008;57:451-5.

36. Floegel A, Kim D-O, Chung S-J, Koo SI, Chun OK. Comparison of ABTS/DPPH assays to measure antioxidant capacity in popular antioxidant-rich US foods. J Food Compos Anal. 2011;24:1043-8. 
37. Li ZL, Liu JC, Hu J, Li XQ, Wang SW, Yi DH, Zhao MG. Protective effects of hyperoside against human umbilical vein endothelial cell damage induced by hydrogen peroxide. J Ethnopharmacol. 2012;139:388-94.

38. Dall'Agnol R, Ferraz A, Bernardi AP, Albring D, Nor C, Sarmento L, Lamb L, Hass M, Von Poser G, Schapoval EES. Antimicrobial activity of some Hypericum species. Phytomedicine. 2003;10:511-6.

39. Thibane VS, Ells R, Hugo A, Albertyn J, van Rensburg WJ, van Wyk PW, Kock $\mathrm{J}$, Pohl CH. Polyunsaturated fatty acids cause apoptosis in C. albicans and C. dubliniensis biofilms. Biochim Biophys Acta Gen Subj. 2012;1820:1463-8.

40. Johansson A-C, Appelqvist H, Nilsson C, Kågedal K, Roberg K, Öllinger K. Regulation of apoptosis-associated lysosomal membrane permeabilization Apoptosis. 2010;15:527-40

Ready to submit your research? Choose BMC and benefit from:

- fast, convenient online submission

- thorough peer review by experienced researchers in your field

- rapid publication on acceptance

- support for research data, including large and complex data types

- gold Open Access which fosters wider collaboration and increased citations

- maximum visibility for your research: over $100 \mathrm{M}$ website views per year

At $\mathrm{BMC}$, research is always in progress.

Learn more biomedcentral.com/submissions 